EXTENDED REPORT

\title{
Differential effects of leflunomide and methotrexate on cytokine production in rheumatoid arthritis
}

\author{
M C Kraan, T J M Smeets, M J van Loon, F C Breedveld, B A C Dijkmans, P P Tak
}

Ann Rheum Dis 2004;63:1056-1061. doi: 10.1136/ard.2003.014738

\begin{abstract}
See end of article for authors' affiliations

Correspondence to: Professor P P Tak, Division of Clinical Immunology and Rheumatology, Department of Internal Medicine, University of Amsterdam/Academic Medical Centre, Meibergdreef 9, $1105 \mathrm{AZ}$ Amsterdam, The Netherlands; p.p.tak@ amc.uva.nl
\end{abstract}

Accepted 19 April 2004 Published online first 28 April 2004
Background: T cells have a pivotal role in RA. Leflunomide inhibits pyrimidine biosynthesis, to which T cells are especially susceptible, and therefore may have a different cytokine profile than methotrexate.

Materials and methods: Serum samples of 100 patients with RA, treated with leflunomide $(n=50)$ or methotrexate $(n=50)$, were collected at baseline, after 16 weeks and after 1 year's treatment. Serum levels of interleukin 6 (IL6), and interferon (IFN) $\gamma$ were determined by ELISA. Additionally, peripheral blood mononuclear cells (PBMC) of five healthy volunteers and three patients with RA were isolated and the effects of the active metabolite of leflunomide (A77-1726, 0-200 mmol/l) on cell proliferation and on IL6 and IFN $\gamma$ production were determined by ELISA. In peripheral blood lymphocytes (PBL) and monocytes (PBM) from two healthy volunteers the effects of A77-1726 on IL6 production were measured by ELISA and PCR.

Results: Mean (SEM) serum levels of IFN $\gamma$ were significantly reduced after leflunomide treatment (baseline $43(10) \mathrm{pg} / \mathrm{ml} ; 1$ year $29(7)(p=0.015)$, but there was no change in IL6 levels (baseline $158(41), 1$ year 151 (48)). Both IFN $\gamma$ and IL6 levels were significantly reduced after methotrexate treatment. This observation was supported by in vitro experiments. The production of IFN $\gamma$ by PBL was inhibited by A771726, but IL6 production by PBM was not inhibited.

Conclusion: The differential effect on IFN $\gamma$ and IL6 production supports the hypothesis that activated T cells are preferentially inhibited by leflunomide. An explanation may be either inhibition of uridine synthesis or effects on signal transduction pathways. eflunomide inhibits both synovial inflammation and join destruction in patients with rheumatoid arthritis (RA). ${ }^{1-3}$ -In vivo, leflunomide acts as a pro-drug and is quickly metabolised into the active metabolite A77-1726 in the gut wall and liver. Most of the in vitro pharmacodynamic studies have, therefore, been conducted with the active metabolite A77-1726 rather than with leflunomide.

The mechanism of action has been described in three excellent reviews. ${ }^{4-6}$ In summary, at least two modes of action of leflunomide have been documented: inhibition of dihydro-orotate dehydrogenase (DHODH), by which leflunomide influences the de novo pyrimidine biosynthesis, ${ }^{7}$ and interaction with primary and secondary signalling events. ${ }^{8-10}$

The main target of leflunomide seems to be pyrimidine biosynthesis, because leflunomide shows high affinity binding to DHODH, and, even at low concentrations, inhibits the enzyme. ${ }^{6}$ DHODH is essential for the de novo synthesis of uridine monophosphate (UMP), a precursor of pyrimidine nucleotides. Resting lymphocytes have low levels of DHODH and mainly use a salvage pathway for UMP to sustain survival. ${ }^{7}$ Activation of lymphocytes gives a seven- to eightfold increased demand for UMP, which makes these cells susceptible to DHODH inhibition by leflunomide in the absence of a salvage pathway. ${ }^{11}$ DHODH inhibition decreases UMP levels, decreases DNA and RNA synthesis and, consequently, inhibits cell proliferation and Gl phase cell cycle arrest. Other cells are less affected by DHODH because of the use of a salvage pathway. Another argument supporting the proposed inhibitory effects of leflunomide on T cells by DHODH inhibition is the reversal of the observed effects by exogenous uridine in vitro. ${ }^{7}$ Further support is found in the observation that the inhibition of de novo pyrimidine biosynthesis by leflunomide is 100 -fold stronger than its effects on tyrosine kinases. ${ }^{6}$
Leflunomide also affects signal transduction, ${ }^{9}$ interferes with cell-cell contact, ${ }^{12}$ and inhibits tumour necrosis factor $\alpha$ $(\mathrm{TNF} \alpha)$ induced activation of NF- $\kappa \mathrm{B} .{ }^{10}$ Moreover, studies of leflunomide have shown that it affects neutrophil chemotaxis, which cannot directly be explained by effects on purine nucleotides. ${ }^{13}$ Therefore, it has been suggested that the effects on pyrimidine biosynthesis are associated with low doses of leflunomide, whereas other mechanisms might be operative at higher concentrations. ${ }^{4}{ }^{6}$ In registration studies on the treatment of active RA the comparator drug for leflunomide was often methotrexate. The mechanism of action of methotrexate in RA is currently not completely understood but seems to be more than an effect on purine biosynthesis, and appears to be not cell type specific. Whereas the effects of methotrexate on interleukin (IL) $6^{14}$ and interferon $\gamma(\text { IFN } \gamma)^{15}$ levels have previously been demonstrated, there are no data on leflunomide. To provide insight into the beneficial effects of leflunomide in patients with RA we examined the effects of leflunomide on cytokine production by mononuclear cells.

\section{MATERIALS AND METHODS In vivo study}

A total of 100 (50 treated with leflunomide and 50 treated with methotrexate) patients were selected from 999 patients with RA who participated in a prospective, double blind, randomised clinical trial comparing leflunomide and methotrexate. ${ }^{16}$ Firstly, sites with a large number of patients

\footnotetext{
Abbreviations: CRP, C reactive protein; DAS, disease activity score; $\mathrm{DHODH}$, dihydro-orotate dehydrogenase; ELISA, enzyme linked immunosorbent assay; IFN, interferon; IL, interleukin; LPS, lipopolysaccharide; mAb, monoclonal antibody; PBL, peripheral blood lymphocytes; PBM, peripheral blood monocytes; PBMC, peripheral blood mononuclear cells; PCR, polymerase chain reaction; PHA, phytohaemagglutinin; RA, rheumatoid arthritis; TNF, tumour necrosis factor; UMP, uridine monophosphate
} 
Table 1 Demographics, clinical data, and cytokine measurements of the patients with RA studied

\begin{tabular}{|c|c|c|c|c|c|c|c|c|c|c|}
\hline & \multicolumn{5}{|c|}{ Leflunomide* $(n=50)$} & \multicolumn{5}{|c|}{ Methotrexate $^{*}(n=50)$} \\
\hline & Baseline & 4 Months & p Value & 1 Year & p Value & Baseline & 4 Months & p Value & 1 Year & p Value \\
\hline $\begin{array}{l}\text { DAS } \\
\text { CRP (mg/l) } \\
\text { Interferon } \gamma(\mathrm{pg} / \mathrm{ml}) \\
\text { Interleukin } 6(\mathrm{pg} / \mathrm{ml})\end{array}$ & $\begin{array}{l}6.9(0.1) \\
5.3(0.9) \\
43(10) \\
158(41)\end{array}$ & $\begin{array}{l}5.6(0.2) \\
2.2(0.5) \\
38(8) \\
180(67)\end{array}$ & $\begin{array}{l}<0.0001 \\
<0.0001 \\
\text { NS } \\
\text { NS }\end{array}$ & $\begin{array}{l}5.2(0.2) \\
2.1(0.5) \\
29(7) \\
151(48)\end{array}$ & $\begin{array}{l}<0.0001 \\
<0.0001 \\
0.015 \\
\text { NS }\end{array}$ & $\begin{array}{l}7.0(0.1) \\
3.5(0.4) \\
57(10) \\
107(23)\end{array}$ & $\begin{array}{l}5.3(0.2) \\
1.3(0.2) \\
44(7) \\
93(25)\end{array}$ & $\begin{array}{l}<0.0001 \\
<0.0001 \\
\text { NS } \\
0.02\end{array}$ & $\begin{array}{l}4.2(0.2) \\
0.9(0.2) \\
36(6) \\
80(20)\end{array}$ & $\begin{array}{l}<0.0001 \\
<0.0001 \\
0.046 \\
0.05\end{array}$ \\
\hline
\end{tabular}

Results are given as mean (SEM)

*Patients receiving leflunomide were aged 62 (range 46-75) years, with mean (SEM) disease duration 49 (6) months; patients receiving methotrexate were aged $58(22-74)$ years, with disease duration $42(5)$ months.

enrolled were selected to minimise variance in sampling, processing, and sending to a centralised laboratory. Samples were stored at $-80^{\circ} \mathrm{C}$ and shipped to our centre for analysis 4-5 years after sampling. No data are available on stability, but all samples were subject to the same conditions. As a result the serum samples of six study sites were used. For all 100 patients (50 leflunomide, 50 methotrexate) serum samples from baseline, after 4 months, and after 1 year were available and tested. Clinical variables included the disease activity score (DAS) and $\mathrm{C}$ reactive protein (CRP), measured at the same times. Patients were treated with either leflunomide $20 \mathrm{mg} /$ day after a loading dose of $100 \mathrm{mg} /$ day for the first 3 days or methotrexate $15 \mathrm{mg} /$ week (initial dose $7.5 \mathrm{mg} /$ week, increased to $10 \mathrm{mg} /$ week 4 weeks after baseline, and increased to $15 \mathrm{mg} /$ week 8 weeks after baseline). At baseline all disease modifying antirheumatic drugs were washed out and only concomitant non-steroidal antiinflammatory drug and low dose prednisone $(\leqslant 10 \mathrm{mg} /$ day $)$ treatment was allowed

\section{Measurement of cytokine production in patients with RA}

The in vivo production of IL6 was measured by enzyme linked immunosorbent assay (ELISA) using a monoclonal antihuman IL6 antibody (R\&D catalogue No MAB206), and IFN $\gamma$ was measured by ELISA using a monoclonal antihuman IFN $\gamma$ antibody (R\&D catalogue No DIF50). For both assays the manufacturer's specifications were used.

\section{In vitro experiments}

To investigate the observations made in vivo in more detail we tested the effects of methotrexate and A77-1726 on peripheral blood mononuclear cells (PBMC), peripheral blood lymphocytes (PBL), and peripheral blood monocytes (PBM) in vitro. A77-1726 (the active metabolite of HWA486) obtained in powder form (kindly provided by Dr RR Bartlett, Aventis Pharma, Wiesbaden, FRG), was diluted at the appropriate concentrations $(0.1-200 \mu \mathrm{mol} / \mathrm{l}$, clinically relevant concentration is $\pm 20 \mu \mathrm{mol} / \mathrm{l})$.

\section{Cells}

PBMC of five healthy volunteers and three patients with RA were prepared using Ficoll density centrifugation. No major differences were found and, therefore, pooled results are presented of experiments in duplicate. In two healthy volunteers the fractions of PBL and PBM were further purified by countercurrent centrifugation; the preparations contained more than $80 \%$ PBL or PBM, and the viability was more than $95 \%$ as assessed by trypan blue exclusion.

\section{Stimulation}

Cells were stimulated with $5 \mu \mathrm{g} / \mathrm{ml}$ phytohaemagglutinin (PHA; Murex Diagnostics Ltd, Dartford, UK), $5 \mu \mathrm{g} / \mathrm{ml}$ lipopolysaccharide (LPS; Sigma, St Louis, USA), $5 \mu \mathrm{g} / \mathrm{ml}$ anti-CD2 monoclonal antibody (mAb) (CLB-CD2), $5 \mu \mathrm{g} / \mathrm{ml}$ anti-CD3 mAb Okt3 (CLB-CD3, CLB, Amsterdam, The
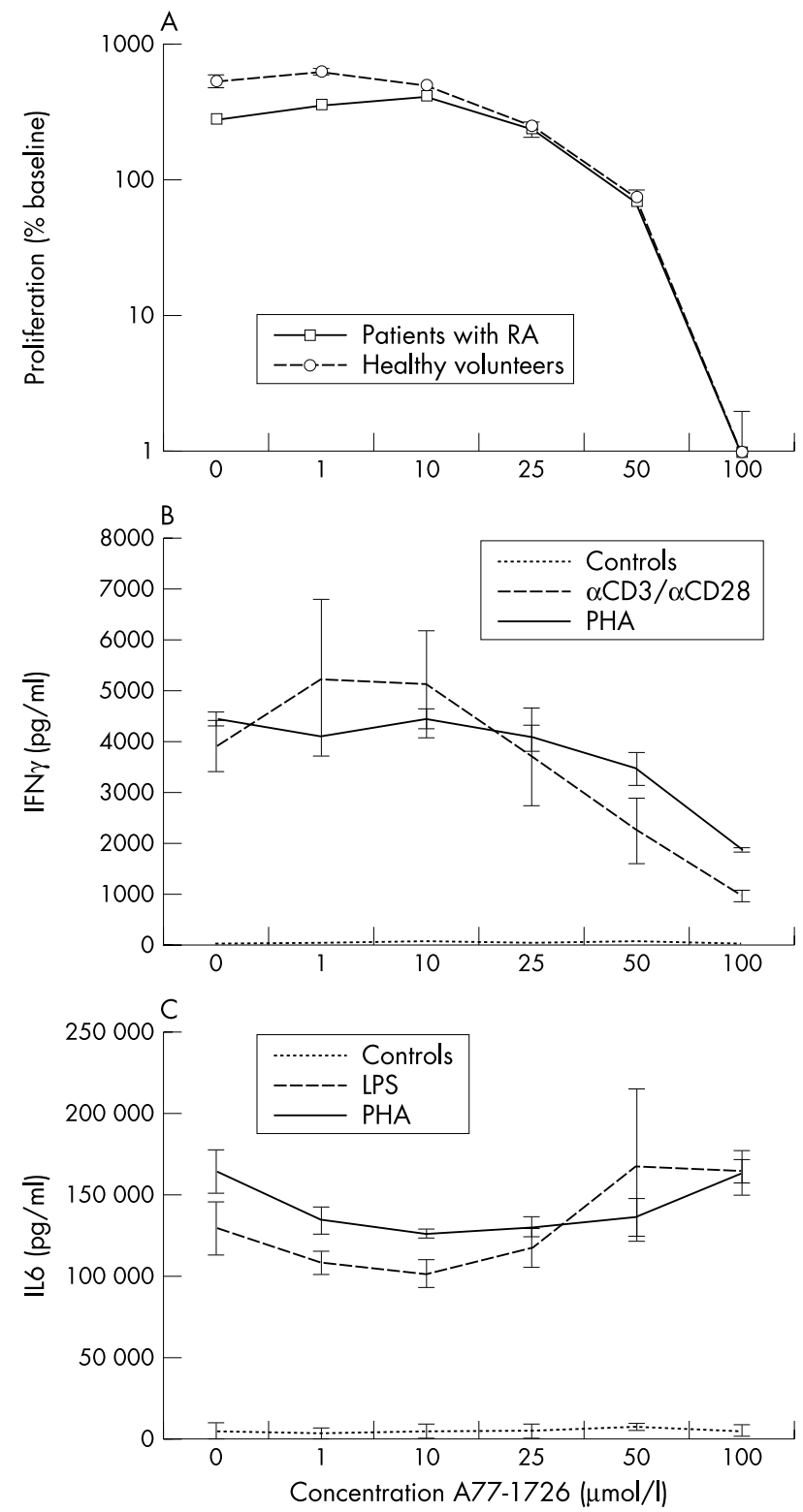

Figure 1 (A) Incorporation of $\left[{ }^{3} \mathrm{H}\right]$ thymidine by PBMC of healthy donors and patients with RA after stimulation with LPS. Graph depicts the number of counts as measured after 24 hours of incubation in the presence of various concentrations of leflunomide $(0-100 \mu \mathrm{mol} / \mathrm{l})$. (B) Production of IFN $\gamma(\mathrm{pg} / \mathrm{ml})$ by PBMC after 36 hours. Depicted are controls and cells stimulated with PHA in the presence of various concentrations of leflunomide $(0-100 \mu \mathrm{mol} / \mathrm{l})$. (C) Production of IL6 $(\mathrm{pg} / \mathrm{ml})$ by PBMC after 8 hours. Depicted are controls and cells stimulated with PHA in the presence of various concentrations of leflunomide $(0-100 \mu \mathrm{mol} / \mathrm{l})$. 
Netherlands), and $5 \mu \mathrm{g} / \mathrm{ml}$ anti-CD28 mAb 15E8 (CLB$\mathrm{CD} 28 / 1)$. The various stimuli were added to the PBMC, PBL, or PBM together with A77-1726 and tests carried out at intervals between 4 and 72 hours.

\section{Proliferation experiments}

Overnight, 96 well culture plates (Greiner, Alphen a/d Rijn, The Netherlands) were coated with anti-CD3 mAb or LPS. PBMC and PBL (two donors) were plated $\left(2 \times 10^{5}\right.$ cells/well) and incubated with or without A77-1726 for 48 hours (24 hours after initiation $20 \mu \mathrm{Ci}\left[{ }^{3} \mathrm{H}\right]$ thymidine $/ \mathrm{ml}, 0.05 \mathrm{ml} /$ well, was added). Cells were harvested and the rate of DNA synthesis was measured. Experiments were performed in triplicate.

\section{Cytokine measurement}

Experiments were performed in 24 well tissue culture plates $\left(1 \times 10^{6}\right.$ cells/well $)$. For the determination of IL6 an ELISA was used with antihuman IL6 mAb (mAbl6; Department of Nephrology LUMC, Leiden, The Netherlands); sensitivity was $1 \mathrm{pg} / \mathrm{ml}$. For the determination of IFN $\gamma$ an ELISA was used with anti-IFN $\gamma$ mAb (MD2, CLB); sensitivity was $0.2 \mathrm{ng} / \mathrm{ml}$.

For all experiments cell vitality and cell death were estimated by trypan blue exclusion and a lactate dehydrogenase test (Boehringer Mannheim Cytotoxicity kit, catalogue No 1644793 ). The results obtained could not be attributed to the effects of cell death in any of the experiments. Addition of uridine together with A77-1726 at incubation abolished all observed effects of A77-1726 alone.

RNA preparation, cDNA synthesis, semiquantitative polymerase chain reaction (PCR) on PBM

In PHA stimulated PBM, RNA encoding IL6 and $\beta_{2^{-}}$ microglobulin was measured by PCR as described previously. ${ }^{17}$ In brief, total RNA was isolated with RNAzol (Cinna/Biotecx Laboratories Inc, Houston, TX, USA), according to the manufacturer's description. Total RNA $(2 \mu \mathrm{g})$ was converted into first strand cellular cDNA using oligo-dT primers (Gibco BRL, Breda, The Netherlands). Relative quantification of mRNA was based on the usage of synthetic DNA (st-DNA $=$ pQA-1) that contains sequences that are complementary to the cytokine-specific PCR primers used and result in an amplification of different length than the specific amplicon. Titration experiments were carried out with various amounts of synthetic DNA added to a fixed amount of cellular cDNA. The titration used the intensity of the internal standard product and the specific IL6 PCR was equal, so the amount of IL6 product could be estimated. $\beta_{2^{-}}$ Microglobulin mRNA was used for standardisation of the different RNA samples. The ratio between IL6 mRNA and $\beta_{2^{-}}$ microglobulin mRNA was used to assess the relative levels of the specific mRNA between the various samples. The PCR mix (final volume $40 \mu \mathrm{l}$ ) consisted of $1 \mu \mathrm{l}$ of a $1: 10$ dilution of cellular cDNA, $2.5 \mathrm{nM}$ of each dNTP, $50 \mathrm{mM} \mathrm{KCl}, 10 \mathrm{mM}$
Tris-HCL $\quad(\mathrm{pH} 8.4), 2 \mathrm{mM} \quad \mathrm{MgCl}_{2}, \quad 0.06 \%$ bovine serum albumin, $0.87 \mathrm{U}$ DNA taq polymerase (Perkin Elmer, Gouda, The Netherlands), and $10 \mathrm{pmol}$ of each specific sense and antisense primer (Isogen Bioscience, Maarssen, The Netherlands): $\beta_{2}$-microglobulin sense primer 5'GCAGCAGCG AATGGAAAGTC $3^{\prime}, \quad \beta_{2}$-microglobulin antisense primer 5'GATCCTGCTTACATGGTCTCG 3', TNF $\alpha$ sense primer 5'ACCCGCCTGTAGCCCATGTT 3', TNF $\alpha$ antisense primer 5'AAAGTAGACTTGCCCAGACT 3'.

\section{Statistical analysis}

Wilcoxon signed rank test for paired samples was used to test the changes from the baseline measurement. Student $t$ tests were used to compare the two treatment groups. Spearman's test were used to test correlations between CRP and IL6.

\section{RESULTS}

\section{Study patients}

Table 1 shows the demographic and clinical data of the patients. All patients had active disease at baseline, as measured by the mean (SEM) DAS of $6.9(0.1)$ for the leflunomide patients and $7.0(0.1)$ for the methotrexate patients, with a significant reduction after 4 months, and after 1 year in both leflunomide and methotrexate treated patients (table 1). The CRP levels were significantly reduced in both leflunomide and methotrexate patients (table 1), but in line with previous results ${ }^{18}$ the CRP levels were significantly lower after 1 year of treatment with methotrexate $(p=0.014)$.

\section{In vivo cytokine measurements}

Leflunomide significantly inhibited mean (SEM) IFN $\gamma$ production: baseline 43 (10) pg/ml, l year 29 (7) pg/ml $(\mathrm{p}=0.015)$, whereas IL6 remained unchanged (baseline 158 (41) pg/ml, l year 151 (48) pg/ml) (table 1). Methotrexate also significantly inhibited IFN $\gamma$ levels: baseline 57 (10) pg/ $\mathrm{ml}$ to $36(6) \mathrm{pg} / \mathrm{ml}$ after $\mathrm{l}$ year $(\mathrm{p}=0.046)$, but in contrast with the findings in the leflunomide treated patients IL6 was also inhibited significantly at 4 months and after 1 year: baseline 107 (23) pg/ml, 4 months 93 (25) pg/ml ( $\mathrm{p}=0.020)$, and 1 year $80(20) \mathrm{pg} / \mathrm{ml}(\mathrm{p}=0.05)$ (table 1$)$.

At baseline there was a significant correlation between serum IL6 levels and serum CRP $\left(r_{\mathrm{s}}=0.296, \mathrm{p}=0.003\right)$; this correlation was sustained at 4 months for methotrexate patients $\left(r_{\mathrm{s}}=0.579, \mathrm{p}<0.0001\right)$, but not for leflunomide $\left(r_{\mathrm{s}}=0.274\right.$, NS). After 1 year there was no significant correlation between CRP levels and IL6 in either leflunomide or methotrexate treated patients.

\section{In vitro studies}

A77-1726 completely inhibited mitogen induced proliferation of PBMC by LPS and PHA (PHA and patients with RA, control 59650 (8835) counts (mean (SEM)), $100 \mu \mathrm{M}$

\begin{tabular}{|c|c|c|c|c|}
\hline \multirow[b]{2}{*}{$\begin{array}{l}\text { A77-1726 } \\
\text { ( } \mu \mathrm{mol} / \mathrm{I})\end{array}$} & \multicolumn{2}{|l|}{ Baseline } & \multicolumn{2}{|l|}{48 Hours } \\
\hline & $\begin{array}{l}\text { Controls } \\
(n=5)\end{array}$ & $\begin{array}{l}\text { Patients with RA } \\
(\mathrm{n}=3)\end{array}$ & $\begin{array}{l}\text { Controls } \\
(\mathrm{n}=5)\end{array}$ & $\begin{array}{l}\text { Patients with RA } \\
(\mathrm{n}=3)\end{array}$ \\
\hline 0 & $0(0)$ & $0(0)$ & $18549(2772)$ & $4484(120)$ \\
\hline 1 & $12(36)$ & $0(0)$ & $13500(7267)$ & 4144 (12) \\
\hline 10 & $0(0)$ & 0 (0) & 15990 (6193) & 4474 (198) \\
\hline 25 & 0 (0) & $0(0)$ & $10950(6383)$ & 4106 (258) \\
\hline 50 & $0(0)$ & 0 (0) & 7830 (4848) & 3488 (320) \\
\hline 100 & $0(0)$ & 0 (0) & 6810 (2001) & $1888(32)$ \\
\hline
\end{tabular}




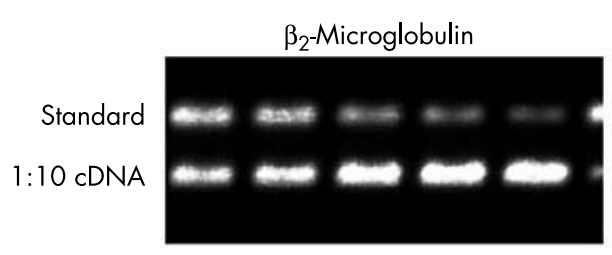

Ratio

0.015

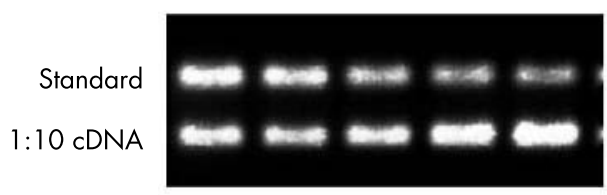

Ratio

0.015

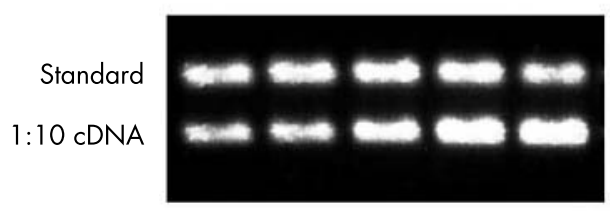

Ratio

0.02

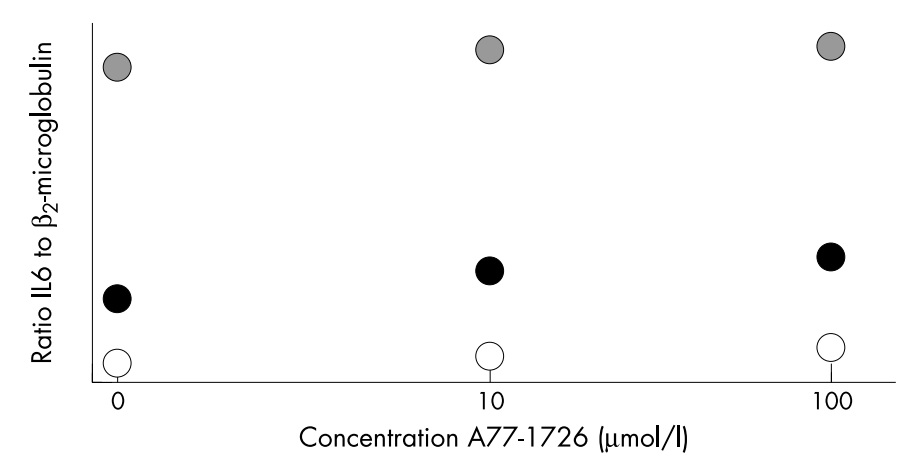

IL6 RNA

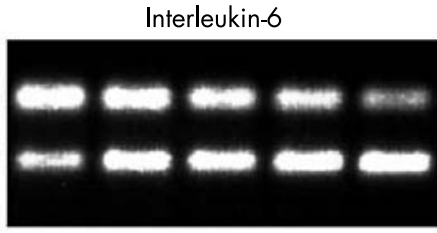

$0 \mu \mathrm{mol} / \mathrm{l}$

A77-1726

0.05

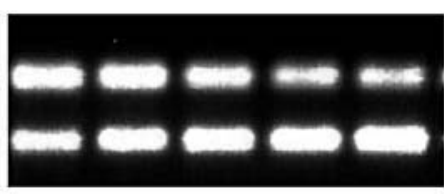

$10 \mu \mathrm{mol} / \mathrm{l}$

A77-1726

0.08

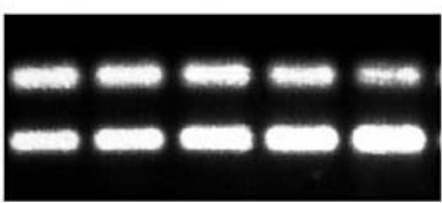

$100 \mu \mathrm{mol} / \mathrm{I}$

A77-1726

0.1

Table 3 Interleukin 6 production $(\mathrm{pg} / \mathrm{ml}$ ) by PBMC of patients with RA and healthy controls at baseline and 24 hours after stimulation with PHA $5 \mu \mathrm{g} / \mathrm{ml}$. Also given are measurements in density centrifugation isolated PBM of healthy controls 8 hours after stimulation with PHA and PBL 16 hours after stimulation with $\alpha \mathrm{CD} 3 / \alpha C D 28$

\begin{tabular}{|c|c|c|c|c|c|c|}
\hline \multirow[b]{2}{*}{$\begin{array}{l}\text { A77-1726 } \\
(\mu \mathrm{mol} / \mathrm{l})\end{array}$} & \multicolumn{2}{|c|}{$\begin{array}{l}\text { PBMC } \\
\text { (unstimulated) } \\
\text { Baseline }\end{array}$} & \multicolumn{2}{|c|}{$\begin{array}{l}\text { PBMC } \\
\text { (stimulated with PHA) } \\
24 \text { Hours }\end{array}$} & \multirow{2}{*}{$\begin{array}{l}\text { PBM } \\
\text { (stimulated with PHA) } \\
8 \text { Hours } \\
\text { Controls } \\
(\mathrm{n}=2)\end{array}$} & \multirow{2}{*}{$\begin{array}{l}\text { PBL (stimulated } \\
\text { with } \alpha C D 3 / \alpha C D 28) \\
16 \text { Hours } \\
\text { Controls } \\
(n=2)\end{array}$} \\
\hline & $\begin{array}{l}\text { Controls } \\
(n=5)\end{array}$ & $\begin{array}{l}\text { Patients with RA } \\
(\mathrm{n}=3)\end{array}$ & $\begin{array}{l}\text { Controls } \\
(n=5)\end{array}$ & $\begin{array}{l}\text { Patients with RA } \\
(n=3)\end{array}$ & & \\
\hline 0 & $0(0)$ & $110(11)$ & 13967 (4937) & $12880(1640)$ & 24306 (3761) & $2320(420)$ \\
\hline 1 & $0(0)$ & $183(97)$ & 12033 (3134) & $10700(680)$ & ND & \\
\hline 10 & $0(0)$ & $0(0)$ & 15067 (3162) & $10035(815)$ & ND & 2070 (185) \\
\hline 25 & $0(0)$ & 175 (175) & 14600 (2872) & $11700(1200)$ & ND & ND \\
\hline 50 & $0(0)$ & 198 (53) & 12633 (4513) & $16745(4685)$ & $25325(2118)$ & $2110(340)$ \\
\hline 100 & $0(0)$ & $133(83)$ & 21300 (4198) & 16385 (725) & 57203 (18221) & $2370(255)$ \\
\hline
\end{tabular}

Results are given as mean (SEM).

ND, not done. 
A77-1726 1744 (661); $\mathrm{p}<0.05$ ) (fig 1A) in a dose dependent fashion in both patients with RA and healthy volunteers.

A77-1726 reduced IFN $\gamma$ production by PBMC after stimulation with PHA in a dose dependent way in healthy controls (control 18549 (2772) pg/ml, $100 \mu \mathrm{M}$ A77-1726 6810 (2001) pg/ml; $\mathrm{p}<0.05$ ) (table 2, fig 1B) and patients with RA (control 4484 (120) pg/ml, $100 \mu \mathrm{M}$ A77-1726 1888 (32) $\mathrm{pg} / \mathrm{ml} ; \mathrm{p}<0.05)$. Stimulation with anti-CD3/anti-CD28 resulted in comparable results (fig $1 \mathrm{~B}$ ). In PBL there was also a dose dependent inhibition (control $33020 \mathrm{pg} / \mathrm{ml}, 100 \mu \mathrm{M}$ A77-1726 $6550 \mathrm{pg} / \mathrm{ml}$ ). PBM were not tested for IFN $\gamma$ production.

Consistent with the in vivo data we observed no effect of A77-1726 on production of IL6 by PBMC after stimulation with PHA (control 13967 (4937) pg/ml (mean (SEM), $100 \mu \mathrm{M}$ A77-1726 21300 (4198) pg/ml (fig lC). Stimulation with LPS resulted in comparable results (fig lC). In addition, A77-1726 did not affect IL6 gene expression or protein production by PBM (baseline 24306 (3761) pg/ml, $100 \mu \mathrm{M}$ A77-1726 $57203 \quad$ (18 221) pg/ml) (fig 2). As expected, IL6 production by PBL was very low at baseline and did not change in the presence of A77-1726 (table 3).

\section{DISCUSSION}

We observed inhibition of IFN $\gamma$ but not of IL6 in patients with RA treated with leflunomide and, as previously described, inhibition of IL6 ${ }^{14}$ and IFN $\gamma^{15}$ by methotrexate. Stimulation of PBMC, PBL, and PBM confirmed the lack of effect on IL6 production with a dose dependent inhibition of IFN $\gamma$ production and proliferation by A77-1726. ${ }^{819-21}$

An understanding of the mechanism of action of new immunomodulating drugs, in the treatment of RA can be obtained from data on in vitro and in vivo cytokine production, which can provide vital information on the targets of the investigated substance. ${ }^{10}$ As cytokines may reflect differential pharmacodynamic effects of leflunomide and methotrexate on inflammation we focused on the $\mathrm{T}$ cell related cytokine IFN $\gamma$ and the macrophage related cytokine IL6.

Serum IL6 levels of patients with RA have been associated with disease outcome, ${ }^{22}$ but failed to correlate with disease activity in patients with RA treated with methotrexate, ${ }^{23}$ as demonstrated in our study. During phase III studies with leflunomide a remarkable observation was the significant clinical improvement with only modest changes in erythrocyte sedimentation rate and CRP, especially when compared with methotrexate. This relative lack of change in acute phase response after leflunomide treatment is consistent with a limited effect on IL6 production and a more T cell directed mechanism of action. ${ }^{24}$

The T cell derived cytokine IFN $\gamma$ is also produced by natural killer cells (NK cells) and is involved in nearly all phases of inflammation and in the regulation of inflammatory responses. It has effects on macrophage, $\mathrm{B}$ cell, and neutrophil function. The inhibition of IFN $\gamma$, as seen in this study, might be the result of inhibition of DHODH, which impairs T cell function with, as secondary effect, inhibition of monocyte/macrophage function. This is supported by the inhibition which occurs at concentrations of active metabolite present in patients with RA. ${ }^{1}$ The effects of leflunomide on IFN $\gamma$ production shown in this study confirm and extend previous work in animal models of arthritis. ${ }^{27}$ Leflunomide has also been shown to interfere with IFN $\gamma$ induced inducible nitric oxide synthase activation and nitric oxide production in fibroblast, ${ }^{26}$ probably through the MEK/MAP pathway. ${ }^{27}$ Unfortunately, we could not directly compare in vitro and in vivo use of methotrexate owing to technical problems. However, the limited reports available suggest that the results in an vitro model are comparable with those we observed in vivo. ${ }^{28}{ }^{29}$ Within this context it is important to mention that the effects of methotrexate as purine antagonist are probably limited, ${ }^{30}$ and the beneficial effects are more likely to be mediated through adenosine. ${ }^{31-33}$ We observed a clear effect of leflunomide on the proliferation of PBMC without signs of cell death. Other authors have demonstrated that $\mathrm{T}$ cells are inhibited by leflunomide in the Gl-S phase. Previously, these phenomena were attributed to an inhibitory effect on phosphorylation of tyrosine kinases, resulting in interference with signalling events. More recent data point strongly towards inhibition of the enzyme DHODH, resulting in a negative effect on pyrimidine biosynthesis and antiproliferative effects. An overview of all the data available suggests that the inhibitory effects of leflunomide are due to a combination of both inhibition of pyrimidine biosynthesis and interference with signalling events. ${ }^{6}$ The relative contribution of each mechanism of action might be dependent on the concentrations of the drug. ${ }^{25}$

In conclusion, we observed a differential effect on cytokine production by leflunomide with a significant inhibition of IFN $\gamma$ production with unchanged IL6 levels. This observation supports the hypothesis that leflunomide preferentially affects activated $\mathrm{T}$ cells. It also supports the clinical observation of different pharmacodynamic profiles for methotrexate and leflunomide. ${ }^{1}$

\section{Authors' affiliations}

M C Kraan, T J M Smeets, M J van Loon, P P Tak, Division of Clinical Immunology and Rheumatology, Academic Medical Centre/University of Amsterdam, Amsterdam, The Netherlands

F C Breedveld, Department of Rheumatology, Leiden University Medical Centre, Leiden, The Netherlands

B A C Dijkmans, Department of Rheumatology, Free University Medical Centre, Amsterdam, The Netherlands

\section{REFERENCES}

1 Weinblatt ME, Kremer JM, Coblyn JS, Maier AL, Helfgott SM, Morrell M, et al. Pharmacokinetics, safety, and efficacy of combination treatment with methotrexate and leflunomide in patients with active rheumatoid arthritis. Arthritis Rheum 1999;7:1322-8.

2 Strand V, Cohen S, Schiff M, Weaver A, Fleischmann R, Cannon G, et al. Treatment of active rheumatoid arthritis with leflunomide compared with placebo and methotrexate. Arch Intern Med 1999;159:2542-50.

3 Kraan MC, Reece RJ, Barg EC, Smeets TJM, Farnell J, Rosenburg R, et al. Modulation of inflammation and metalloproteinase expression in synovial tissue by leflunomide and methotrexate in patients with active rheumatoid arthritis. Findings in a prospective, randomized, double-blind, parallel-design clinical trial in thirty-nine patients at two centers. Arthritis Rheum 2000;8:1820-30.

4 Fox RI, Herrmann ML, Frangou CG, Wahl GM, Morris RE, Strand V, et al. Mechanism of action for leflunomide in rheumatoid arthritis. Clin Immunol 1999;93:198-208.

5 Breedveld FC, Dayer JM. Leflunomide: mode of action in the treatment of rheumatoid arthritis. Ann Rheum Dis 2000;59:841-9.

6 Herrmann ML, Schleyerbach R, Kirschbaum BJ. Leflunomide: an immunomodulatory drug for the treatment of rheumatoid arthritis and other autoimmune diseases. Immunopharmacology 2000;47:273-89.

7 Ruckemann K, Fairbanks LD, Carrey EA, Hawrylowicz CM, Richards DF, Kirschbaum $B$, et al. Leflunomide inhibits pyrimidine de novo synthesis in mitogen-stimulated T-lymphocytes from healthy humans. J Biol Chem 1998;34:21682-91.

8 Chong ASF, Finnegan A, Jiang X, Gebel H, Sankary HN, Foster P, et al. Leflunomide, a novel immunosuppressive agent. The mechanism of inhibition of T cell proliferation. Transplantation 1993;55:1361-6.

9 Siemasko K, Chong AS, Jack HM, Gong H, Williams JW, Finnegan A Inhibition of JAK3 and STAT6 tyrosine phosphorylation by the immunosuppressive drug leflunomide leads to a block in lgG1 production. $J$ Immunol 1998;4:1581-8.

10 Manna SK, Aggarwal BB. Immunosuppressive leflunomide metabolite (A77 1726) blocks TNF-dependent nuclear factor-kB activation and gene expression. J Immunol 1999; 162:2095-102.

11 Hoskin DW, Taylor RM, Makrigiannis AP, James H, Lee TD. Dose-dependent enhancing and inhibitory effects of A77 1726 (leflunomide) on cytotoxic T lymphocyte induction. Int J Immunopharmacol 1998;20:505-13.

12 Deage V, Burger D, Dayer JM. Exposure of T lymphocytes to leflunomide but not to dexamethasone favors the production by monocytic cells of interleukin-1 receptor antagonist and the tissue-inhibitor of metalloproteinases-1 over that of interleukin-1 beta and metalloproteinases. Eur Cytokine Netw 1998;4:663-8. 
13 Kraan MC, de Koster BM, Elferink JG, Post WJ, Breedveld, FC, Tak PP. Inhibition of neutrophil migration soon after initiation of treatment with leflunomide or methotrexate in patients with rheumatoid arthritis: findings in a prospective, randomized, double-blind clinical trial in fiffeen patients. Arthritis Rheum 2000;43:1488-95

14 Barrera P, Haagsma CJ, Boerbooms AM, van Riel PL, Borm GF, van de Putte $L B$, et al. Effect of methotrexate alone or in combination with sulphasalazine on the production and circulating concentrations of cytokines and their antagonists. Longitudinal evaluation in patients with rheumatoid arthritis. Br J Rheumatol 1995;34:747-55.

15 Schuerwegh AJ, van Offel JF, Bridts CH, Stevens WJ, de Clerck LS. Influence of longterm therapy with methotrexate and low dose corticosteroids on type 1 and type 2 cytokine production in CD4+ and CD8+ T lymphocytes of patients with rheumatoid arthritis. J Rheumatol $2001 ; 28$ : 1793-9.

16 Emery P, Breedveld FC, Lemmel EM, Kaltwasser JP, Dawes PT, Gonnor B. A comparison of the efficacy and safety of leflunomide and methotrexate for the treatment of rheumatoid arthritis. Rheumatology (Oxford) 2000;39:655-65.

17 Kloppenburg M, Brinkman BM, Rooii-Diik HH, Miltenburg AM, Daha MR, Breedveld FC, et al. The tetracycline derivative minocycline differentially affects cytokine production by monocytes and T lymphocytes. Antimicrob Agents Chemother 1996;40:934-40.

18 Smolen JS, Emery P. Efficacy and safety of leflunomide in active rheumatoid arthritis. Rheumatology (Oxford) 2000;39(suppl 1):48-56.

19 Morris RE. New small molecule immunosuppressants for transplantation: review of essential concepts. J Heart Lung Transplant 1993;12:S275-86.

20 Zielinski T, Muller HJ, Bartlett RR. Effects of leflunomide (HWA 486) on expression of lymphocyte activation markers. Agents Actions 1993;38(Spec No):C80-2

21 Lang R, Wagner H, Heeg K. Differential effects of the immunosuppressive agents cyclosporine and leflunomide in vivo - leflunomide blocks clonal T cell expansion yet allows production of lymphokines and manifestation of T cellmediated shock. Transplantation 1995;59:382-9.

22 Straub RH, Muller-Ladner U, Lichtinger T, Scholmerich J, Menninger H, Lang B. Decrease of interleukin 6 during the first 12 months is a prognostic marker for clinical outcome during 36 months treatment with disease-modifying antirheumatic drugs. Br J Rheumatol 1997;36:1298-303.
23 Wascher TC, Hermann J, Brezinschek R, Brezinschek HP, WildersTruschnig M, Rainer F, et al. Serum levels of interleukin- 6 and tumournecrosis-factor-alpha are not correlated to disease activity in patients with rheumatoid arthritis after treatment with low-dose methotrexate. Eur J Clin Invest 1994;24:73-5.

24 Bhardwaj N, Santhanam U, Lau LL, Tatter SB, Ghrayeb J, Rivelis M, et al. IL-6/IFN-beta 2 in synovial effusions of patients with rheumatoid arthritis and other arthritides. Identification of several isoforms and studies of cellular sources. J Immunol 1989;143:2153-9.

25 Hoskin DW, Taylor RM, Makrigiannis AP, James H, Lee TD. Dose-dependent enhancing and inhibitory effects of A77 1726 (leflunomide) on cytotoxic T lymphocyte induction. Int J Immunopharmacol 1998:20:505-13.

26 Jankovic V, Samardzic T, Stosic-Grujicic S, Popadic D, Trajkovic V. Cellspecific inhibition of inducible nitric oxide synthase activation by leflunomide. Cell Immunol 2000;199:73-80.

27 Manna SK, Mukhopadhyay A, Aggarwal BB. Leflunomide suppresses TNFinduced cellular responses: effects on NF-kappa B, activator protein-1, c-Jun $\mathrm{N}$-terminal protein kinase, and apoptosis. J Immunol 2000;165:5962-9.

28 Rozman B. Clinical pharmacokinetics of leflunomide. Clin Pharmacokinet 2002:41:421-30.

29 Gerards AH, de Lathouder S, de Groot ER, Dijkmans BA, Aarden LA. Inhibition of cytokine production by methotrexate. Studies in healthy volunteers and patients with rheumatoid arthritis. Rheumatology (Oxford) 2003;42:1189-96.

30 de Lathouder S, Gerards AH, de Groot ER, Valkhof M, Aarden LA. Mycophenolic acid and methotrexate inhibit lymphocyte cytokine production via different mechanisms. Eur Cytokine Netw 2002;13:317-23.

31 van Ede $A E$, Laan RF, De Abreu RA, Stegeman $A B$, van de Putte $L B$. Purine enzymes in patients with rheumatoid arthritis treated with methotrexate. Ann Rheum Dis 2002;61:1060-4.

32 Montesinos MC, Desai A, Delano D, Chen JF, Fink JS, Jacobson MA, et al. Adenosine $\mathrm{A} 2 \mathrm{~A}$ or $\mathrm{A} 3$ receptors are required for inhibition of inflammation by methotrexate and its analog MX-68. Arthritis Rheum 2003;48:240-7.

33 Chan ES, Cronstein BN. Molecular action of methotrexate in inflammatory diseases. Arthritis Res 2002;4:266-73. 